\title{
Bronchodilator Activity in Traditional Medicines: Gift of God Kingdom
}

\author{
Dinesh Kumar ${ }^{1}$, Zulfiqar Ali Bhat ${ }^{1}$, Ishtiaq Ahmad Chashoo', \\ Ramesh S. Deoda ${ }^{2}$, Satish C. Mudgade ${ }^{3}$ and Vijender Kumar ${ }^{1}$ \\ ${ }^{1}$ Department of Pharmaceutical sciences, University of Kashmir, Srinagar, \\ 2Marathawada Mitra Mandal's, College of Pharmacy, Kalewadi, Pimpri, Pune, \\ ${ }^{3} M B E S$ college of Pharmacy, Barshi road Latur, Maharastra,
}

India

\section{Introduction}

Since ancient times humanity has depended on the diversity of plant resources for food, clothing, shelter, and traditional medicine to cure myriads of ailments. Early humans recognized their dependence on nature in both health and illness. Physical evidence of the use of herbal remedies has been found some 60,000 years ago in a burial site of a Neanderthal man uncovered in 1960 in a cave in northern Iraq. Here, scientists found great quantities of plant pollen, some of which came from medicinal plants still used today. The first written records detailing the use of herbs in the treatment of illness are in the form of Mesopotamian clay tablet writings and Egyptian papyrus. Led by instinct, taste and experience, primitive men and women treated illness by using plants, animal parts, and minerals that were not part of their usual diet. Primitive people learned by trial and error to distinguish useful plants with beneficial effects from those that were toxic or non-active, and also which combinations or processing methods had to be used to gain consistent and optimal results. Even in ancient cultures, tribal people methodically collected information on herbs and developed well-defined herbal pharmacopeias. Traditional medicine evolved over centuries, depending on local flora, culture, and religion.

Nature has been a source of medicinal agents for thousands of years, and an impressive number of modern drugs have been isolated from natural sources, particularly plants and with many based on their use in traditional medicine. By using medicinal chemistry and combinatorial chemical and biosynthetic technology, novel natural product leads will be optimized on the basis of their biological activities to yield effective chemotherapeutic and other bioactive agents (Cragg et. al. 2005).

During the past decades, public interest in natural therapies, namely herbal medicine, has increased dramatically not only in developing countries but mainly in industrialized countries (Calixto, 2000). The market for ayurvedic medicines is estimated to be expanding at $20 \%$ annually. Sales of medicinal plants have grown by nearly $25 \%$ in India during $1987-$ 96, the highest rate of growth in the world. The global trade in medicinal plants is of the 
order of US\$ 800 million per year. Export statistics available between 1992 and 1995 indicate that India exported about 32,600 tonnes of crude drugs valued at \$US 46 million. China with exports of over 120,000 tons per annum (US\$ 264.5 million) and India with over 32,000 tons per annum dominate the international market. The annual export of medicinal plants from India is valued at Rs. 1200 million. Two of the largest users of medicinal plants are China and India. Traditional Chinese Medicine (TCM) uses over 5000 plant species, India uses about 7000. According to Export Import Bank, the international market for medicinal plant related trade is to the tune of US\$ 60 billion having a growth rate of $7 \%$ per annum. China's share in world herbal market is US\$ 6 billion while India's share is only US\$1 billion. The World Bank estimated global trade in medicinal and aromatic plants and their products at US \$ 5 trillion by $2050 \mathrm{AD}$. Global herbal market is around \$ 70.5 billion with an average annual growth of $10-12 \%$ per annum. In European union, it contributes to around $45 \%(\$ 32$ billion), rest of the Europe 4\% (2.8 billion), North America 10\% (7.8 billion), Asia 19\% (12.2 billion) and others 7\% (4.6 billion) (Handa, 2007).

Complimentary alternative medicine therapies continue to gain popularity as modalities for the treatment of atopic disorders, such as asthma, allergic rhinitis, and atopic dermatitis. In Chinese, Japanese, Korean, Indian, and Western cultures, herbal therapies are commonly used for allergies. Although well controlled scientific studies have been performed for many of the Asian herbal therapies, and some basic studies have been performed for various herbal components (active ingredients), more needs to be done to assess the composite effects of many of these remedies (Zuckerman et al., 2002) Complementary and alternative medicines (CAMs) are used in more than $80 \%$ of the world's population and are becoming an increasing component of the US health care system, with more than $70 \%$ of the population using CAM at least once and annual spending reaching as much as $\$ 34$ billion.

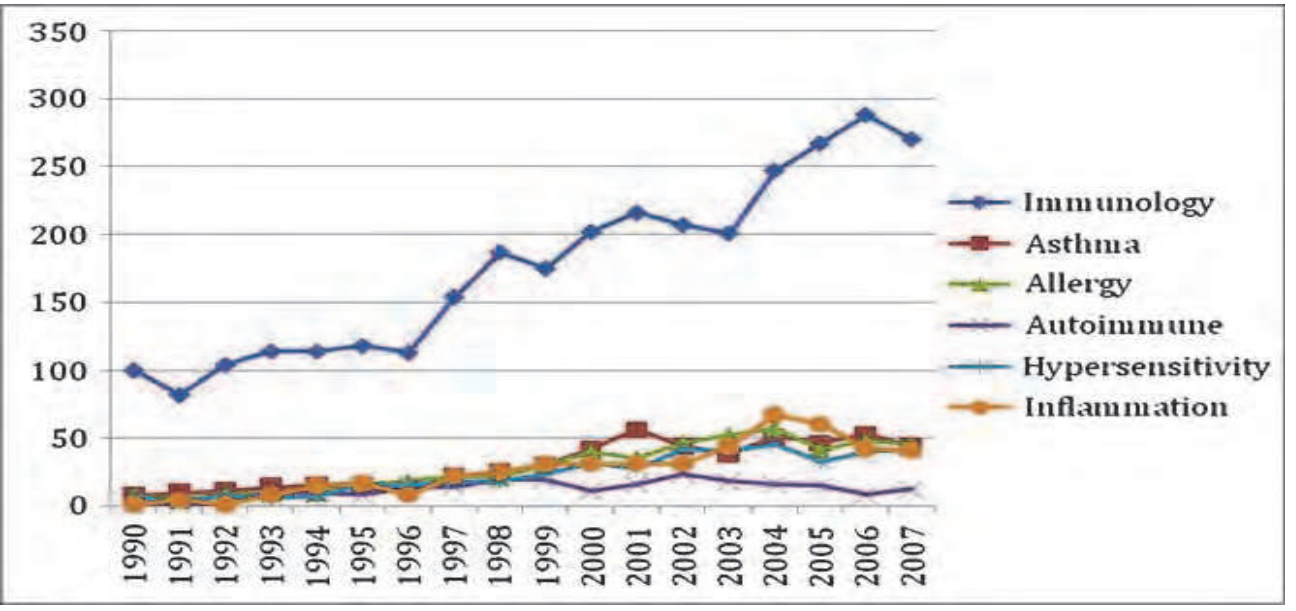

Fig. 1. Annual CAM publications related to allergy and immunology. The numbers of articles published and available for search through PubMed using the search terms complementary medicine and immunology, asthma, allergy, autoimmune, hypersensitivity, or inflammation are shown. 
Since the inception of the National Centre for Complementary and Alternative Medicine, there has been an enormous increase in the number of basic science and therapy-based clinical trials exploring CAM. The subspecialty of allergy and immunology represents a particularly fertile area with a large number of CAM therapies that have been shown to affect the immune system. Research has shown that phytoconstituents such as resveratrol, quercetin, and magnolol may affect transcription factors such as nuclear factor- $\mathrm{kB}$ and the signal transducer and activator of transcription/Janus kinase pathways with resultant changes in cytokines and inflammatory mediators. Clinically, there have been hundreds of trials looking at the effect of CAM on asthma, allergic rhinitis, and atopic dermatitis.

\section{Bronchitis and related diseases}

Bronchitis is described as the inflammation of the bronchial tubes (inflammation = itis). The inflammation causes swelling of the lining of these breathing tubes, narrowing the tubes and promoting secretion of inflammatory fluid.

Bronchiolitis is a term that describes inflammation of the smaller bronchi referred to as bronchioles. In infants, this is usually caused by respiratory syncytial viruses (RSV) and affects the small bronchi and bronchioles more than the large. In adults, other viruses as well as some bacteria can cause bronchiolitis and often manifest as persistent cough and at times production of small plugs of mucus.

Acute bronchitis describes the inflammation of the bronchi usually caused by a viral infection, although bacteria and chemicals may also cause acute bronchitis. Acute bronchitis is a cough that begins suddenly, usually due to a viral infection involving the larger airways. Colds (also known as viral upper airway infections) often involve the throat (pharyngitis) and nasal passages, and at times the larynx (resulting in a diminished hoarse voice, also known as laryngitis). Symptoms can include a runny nose, nasal stuffiness, and sore throat. Croup usually occurs in infants and young children and involves the voice box and upper large airways (the trachea and large bronchi).

Chronic bronchitis for research purposes is defined as a daily cough with sputum production for at least three months, two years in a row. Chronic bronchitis is a diagnosis usually made on the basis of clinical findings of a long term persistent cough usually associated with tobacco abuse. From a pathologic standpoint, characteristic microscopic findings involving inflammatory cells seen in airway tissue samples make the diagnosis. When referring to pulmonary function testing, a decrease in the ratio of the volume of airflow at 1 second when compared to total airflow is less than $70 \%$. This confirms the presence of obstructive airways disease of which chronic bronchitis is one type. Certain findings can be seen on imaging studies (chest X-ray, and CT or MRI of the lungs) to suggest the presence of chronic bronchitis; usually this involves an appearance of thickened tubes.

Asthma: Asthma is a chronic inflammatory disease that affects about 300 million people worldwide, a total that is expected to rise to about 400 million over the next 15-20 years. Most asthmatic individuals respond well to the currently available treatments of inhaled corticosteroids and $\beta$-adrenergic agonists; however, $5-10 \%$ has severe disease that responds poorly. Asthma is a life threatening respiratory condition that causes:

1. The lining of the airways to become swollen

2. The body produces thick mucous 
3. Tightness of the muscle around the airways.

This combination of problems interferes with the exchange of oxygen and carbon dioxide in the lungs Figure 2.
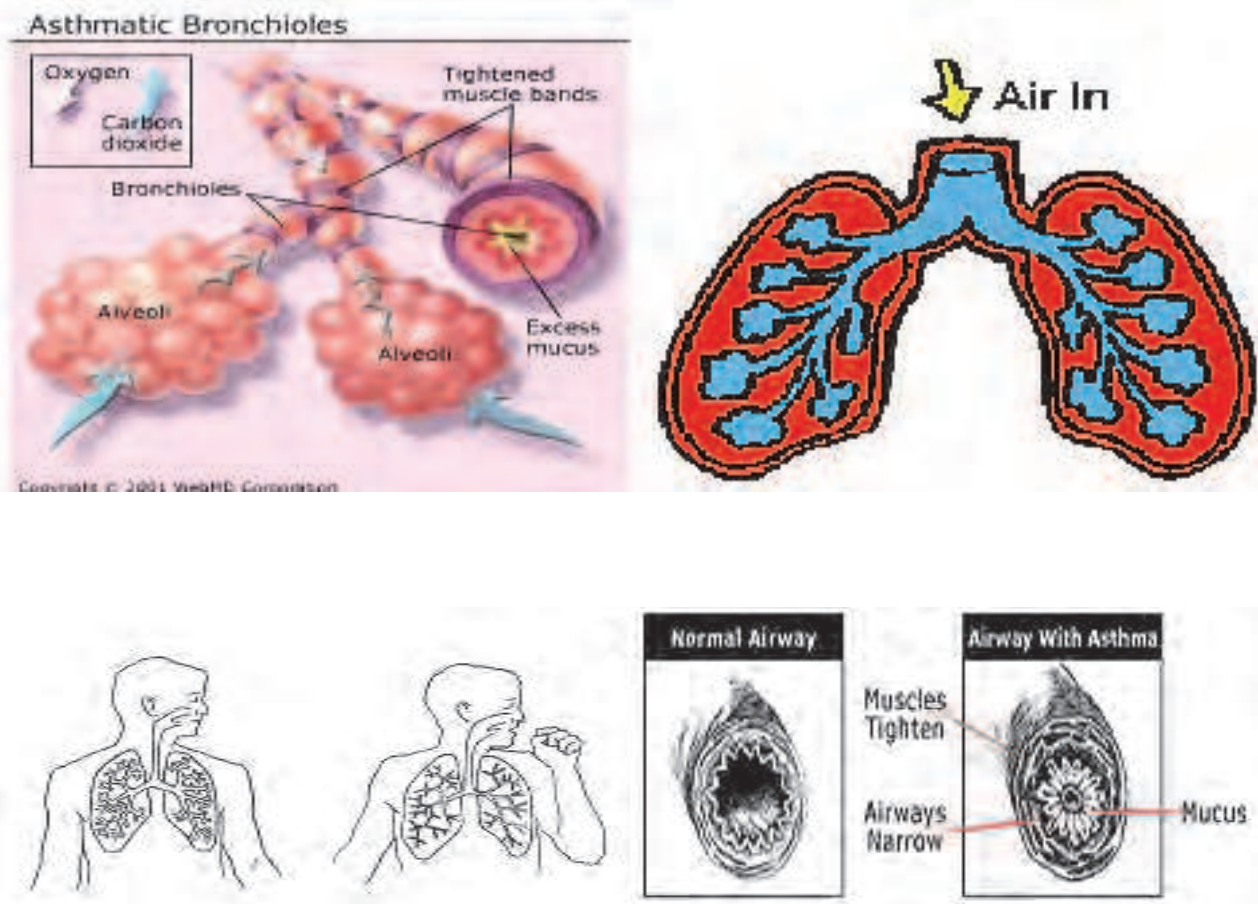

Fig. 2. Bronchitis and related diseases

\section{Symptoms}

- Breathlessness

- Wheezing

- Sputum Production

- Difficulty in talking

- Dyspnoea

- Tightness of Neck Muscle

- Coughing after physical activity

- Whistling Sound while breathing

- Frequent coughing

- Feeling Frightened, exhaustion

- Chest Tightness

- Greyish or bluish colouring of lips 


\section{Trigors or mediators responsible for bronchitis and related diseases}

\begin{tabular}{|c|c|}
\hline List of agents & Events triggering asthma \\
\hline Respiratory infection & $\begin{array}{l}\text { Respiratory syncytial virus (RSV), Rhinovirus, Influenza } \\
\text { and Para-influenza virus, Mycoplasma pneumonia bacteria }\end{array}$ \\
\hline Allergens & $\begin{array}{l}\text { Airborne pollens (grass, trees, weeds), house-dust, mites, } \\
\text { animal dander, cockroaches, fungal spores }\end{array}$ \\
\hline Environment & $\begin{array}{c}\text { Cold air, fog, ozone, sulfur dioxide, nitrogen, tobacco } \\
\text { smoke, wood smoke }\end{array}$ \\
\hline Emotions & Anxiety, stress, laughter \\
\hline Exercise & particularly in cold, dry climate \\
\hline Drugs/preservatives & $\begin{array}{l}\text { Aspirin, NSAIDs, Sulfites, Benzalkonium chloride, } \beta \\
\text { blockers, }\end{array}$ \\
\hline Occupational stimuli & $\begin{array}{c}\text { Bakers (flour dust), farmers (hay mold), spice and enzyme } \\
\text { workers, printers (Arabic gum), chemical workers } \\
\text { (azodyes, anthraquinone, ethylenediamine, toluene, } \\
\text { diisocyanates, PVC), plastics, rubber and wood workers } \\
\text { (formaldehyde, western cedar, dimethylethanolamine, } \\
\text { anhydrides) }\end{array}$ \\
\hline
\end{tabular}

Table 1. List of agents responsible as triggers in bronchitis and related diseases

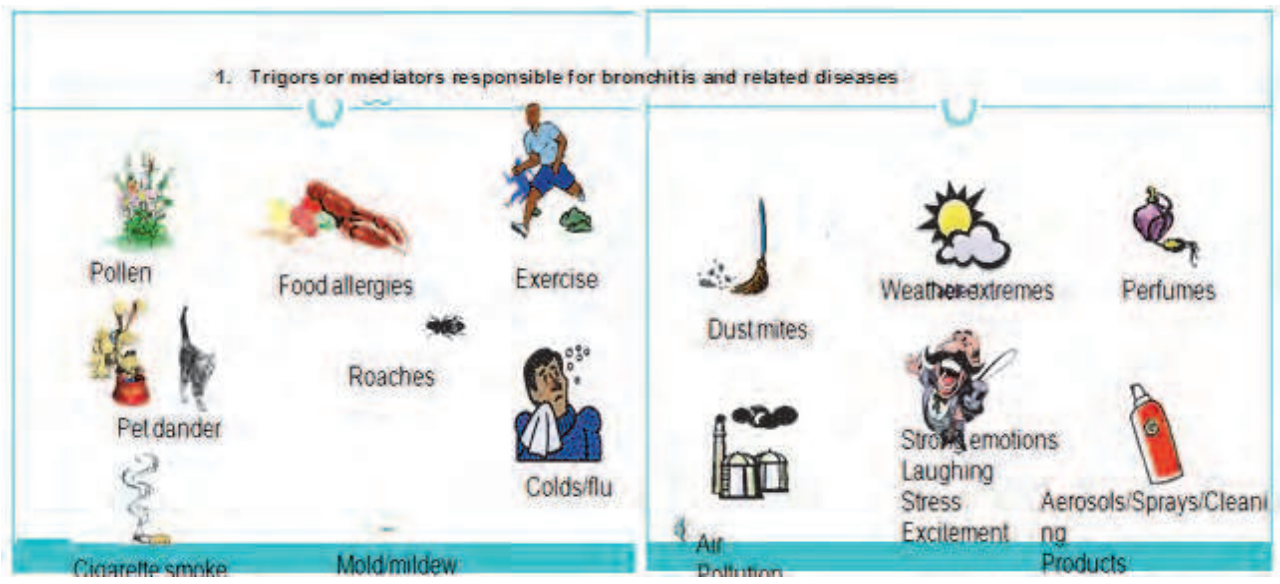

Fig. 3. Agents responsible as triggers in bronchitis and related diseases 


\section{Tradtional medicines as bronchodilator and used in related diseases}

\begin{tabular}{|c|c|c|}
\hline Plants & $\begin{array}{l}\text { Vernacular } \\
\text { name }\end{array}$ & Traditional Uses \\
\hline $\begin{array}{l}\text { Adhatoda zeylanica } \\
\text { Medic. } \\
\text { F: Acanthaceae }\end{array}$ & Addasaramu & $\begin{array}{l}\text { 2-3 spoonfuls of leaf extract given for about a } \\
\text { month. }\end{array}$ \\
\hline $\begin{array}{l}\text { Ailanthus excelsa Roxb. } \\
\text { F: Simaroubaceae }\end{array}$ & Peddamanu & $\begin{array}{l}\text { Bark decoction administered orally in } 2 \text { spoonfuls } \\
\text { thrice a day for about one month }\end{array}$ \\
\hline $\begin{array}{l}\text { Azima tetracantha Lamk. } \\
\text { F:Salvadoraceae }\end{array}$ & Uppi Teega & $\begin{array}{l}\text { Leaf juice administered orally, } 2 \text { spoonfuls, twice a } \\
\text { day for about } 20 \text { days. }\end{array}$ \\
\hline $\begin{array}{l}\text { Bambusa arundinacea } \\
\text { (Retz.) Willd. } \\
\text { F: Gramineae }\end{array}$ & Veduru & $\begin{array}{l}\text { Leaf decoction administered orally, } 3 \text { spoonfuls, } \\
\text { twice a day for about one month. }\end{array}$ \\
\hline $\begin{array}{l}\text { Barleria cuspidata } \\
\text { Heyne.ex Nees } \\
\text { F: Acanthaceae }\end{array}$ & Nelambram & $\begin{array}{l}\text { Root decoction administered orally, } 2 \text { spoonfuls } 3-4 \\
\text { times a day for } 7 \text { days. }\end{array}$ \\
\hline $\begin{array}{l}\text { Barleria prionitis L. } \\
\text { F: Acanthaceae }\end{array}$ & Mulla Gorinta & $\begin{array}{l}\text { Stem ground with honey and ginger , made into } \\
\text { dry pillets and administered , } 2 \text { pillets, twice a day } \\
\text { for amonth. }\end{array}$ \\
\hline $\begin{array}{l}\text { Blumea mollis (D.Don.) } \\
\text { Merr. } \\
\text { F: Compositae }\end{array}$ & Kukka Pogaku & $\begin{array}{l}\text { Dried leaves smoked with wrapping leaves of } \\
\text { Diospyros mealanoxylon }\end{array}$ \\
\hline $\begin{array}{l}\text { Boerhavia diffusa L. } \\
\text { F: Nyctaginaceae }\end{array}$ & Atika Mamidi & $\begin{array}{l}\text { Root extract is administered orally, one spoonful a } \\
\text { day for } 15 \text { days. }\end{array}$ \\
\hline $\begin{array}{l}\text { Calotropis procera (Ait.) } \\
\text { R.Br. } \\
\text { F: Asclepiadaceae }\end{array}$ & Jilledu & $\begin{array}{l}\text { Flower powder mixed with honey and } \\
\text { administered, } 2 \text { spoonfuls, twice a day for a month }\end{array}$ \\
\hline $\begin{array}{l}\text { Cassia fistula L. } \\
\text { F: Leguminosae, } \\
\text { Sf; Caesalpinoideae }\end{array}$ & Rela & $\begin{array}{l}\text { Fruits ground with roots of Hemidesmus and the } \\
\text { paste administered in } 10 \mathrm{~g} \text { twice a day about } 20 \mathrm{~d} .\end{array}$ \\
\hline $\begin{array}{l}\text { Curculigo orchioides } \\
\text { Gaertn. } \\
\text { F: Hypoxidaceae }\end{array}$ & Nela Tadi & $\begin{array}{l}\text { Rhizome extract administered, } 2 \text { spoonfuls, twice a } \\
\text { day for about } 2 \text { months or till cure. }\end{array}$ \\
\hline $\begin{array}{l}\text { Datura metal L. } \\
\text { F: Solanaceae }\end{array}$ & Erri Ummetta & $\begin{array}{l}\text { Fruits ground and made into small pills with } \\
\text { honey and } 2 \text { pills taken twice a day for about } 3 \\
\text { months }\end{array}$ \\
\hline $\begin{array}{l}\text { Desmodium triflorum (L.) } \\
\text { DC. } \\
\text { F:Leguminosae, Sf; } \\
\text { Papilionatae }\end{array}$ & Munta Manda & $\begin{array}{l}\text { Root decoction given in } 2 \text { spoonfuls twice a day for } \\
\text { about } 10 \mathrm{~d} \text {. }\end{array}$ \\
\hline $\begin{array}{l}\text { Lepidagathis cristata } \\
\text { Willd. } \\
\text { F: Acanthaceae }\end{array}$ & Suryakanta & $\begin{array}{l}\text { Powder of shade dried whole plant mixed with } \\
\text { honey in } 2 \text { spoonfuls is administered twice a day } \\
\text { for a bout } 20 \mathrm{~d} \text {. }\end{array}$ \\
\hline
\end{tabular}




\begin{tabular}{lcl}
\hline Plants & $\begin{array}{c}\text { Vernacular } \\
\text { name }\end{array}$ & Traditional Uses \\
\hline
\end{tabular}

Nerium oleander (L.)

F: Apocynaceae

Opuntia stricta (Haw.)

Haw.

F: Cactaceae

Passiflora foetida L.

F: Passifloraceae

Pergularia daemia

(Forssk.) Chiov.

F: Asclepiadaceae

Phyllanthus emblica L.

F: Euphorbiaceae

Phyllanthus reticulatus

Poir.

F: Euphorbiaceae,

Piper longum L.

F: Piperaceae

Portulaca quadrifida L.

F: Portulacaceae

Solanum surattense

Burm.f.

F: Solanaceae

Tragia involucrata L.

F: Euphorbiaceae

Tylophora fasciculata

Ham.

F:ASclepiadaceae

Vicoa indica (L.) DC.

F: Compositae

Vitex negundo L.

F: Verbenaceae

Zaleya decandra (L.)

Burm.f.F: Aizoaceae
Flowers ground with jaggery and the extract

Ganneru. administered in 2 spoonfuls twice a day for about 2 months.

Naga Phanni

Fruits are warmed and the juice given in 2 spoonfuls thrice a day for about 2 weeks.

Leaf decoction administered in 2 spoonfuls with

Tella Jumiki fruit juice of Terminalia chebula thrice a day for about one month.

Dustapa teega Leaf decoction taken in 2 spoonfuls 2-3 times a day for about $15 \mathrm{~d}$.

Fruits ground with tubers of Cyperus rotundus and leaves of Tinospora cordifolia and the paste

Pedda Usiri administered

with honey in 2 spoonfuls twice a day for about one month.

Puli Chettu Root decoction with honey administered in 2 spoonfuls twice a day for one month.

Whole plant ground with leaves of Adhatoda

Pippallu zeylanica and made into powder. A spoonful of powder is taken once in day for $20 \mathrm{~d}$.

Whole plant extract mixed with honey and

Sanna pappu administered in 2 spoonfuls thrice a day for about koora $20 \mathrm{~d}$.

Mulla

Root decoction administered in 2-3 times a day for about one month.

Durada gondi Root powder cigared with leaves if Diospyros melanoxylon and smoked to reduce suffering

Veripala teega Tender leaf juice administered in 2 spoonfuls twice a day for $20-30 d$.

Adavi poddu Leaf juice administered in 2 spoonfuls twice a day tirugudu for $15 \mathrm{~d}$

Vavili Leaf juice with dried powder of Zingiber officinale given in 2 spoonfuls twice a day for about $20 \mathrm{~d}$.

Tella garijelu

Table 2. List of traditional medicinal plant drugs for the treatment of bronchial diseases (Madhu et al., 2010). 


\section{Reported bronchodilators from medicinal plant drugs}

\begin{tabular}{|c|c|c|c|}
\hline Plant & Part used & $\begin{array}{l}\text { Extract/Active } \\
\text { principle }\end{array}$ & Probable action in asthma \\
\hline $\begin{array}{l}\text { Achyranthus } \\
\text { aspera }\end{array}$ & Roots & Oily preparation & $\begin{array}{l}\text { Decreased ESR, Decreased total } \\
\text { Eosinophil count. (Sharadini,1985) } \\
\end{array}$ \\
\hline Adhathoda vasica & \begin{tabular}{|l} 
Leaves \\
Roots
\end{tabular} & Alkaloids & $\begin{array}{l}\text { Bronchodilator, Anti- anaphylactic } \\
\text { (Sharadini,1985) }\end{array}$ \\
\hline Albizzia lebbeck & $\begin{array}{l}\text { Flower, } \\
\text { Bark }\end{array}$ & Decoction & $\begin{array}{l}\text { Anaphylaxis, Histamine Induced } \\
\text { Bronchospsm (Tripathi \& Das,1977) }\end{array}$ \\
\hline $\begin{array}{l}\text { Belamcand } \\
\text { chinensis }\end{array}$ & $\begin{array}{l}\text { Leaves, } \\
\text { Rhizome }\end{array}$ & $\begin{array}{l}50 \% \text { Ethanolic } \\
\text { Extract }\end{array}$ & $\begin{array}{l}\text { Histamine Induced Bronchospasm } \\
\text { (Singh \& Agrawal, 1990) }\end{array}$ \\
\hline $\begin{array}{l}\text { Bupleurum } \\
\text { falcatum }\end{array}$ & Roots & $\begin{array}{l}\text { saikosaponin-A } \\
(\text { SSA), } \\
\text { triterpenoid } \\
\text { glycoside. }\end{array}$ & $\begin{array}{l}\text { Inhibited the passive cutaneous } \\
\text { anaphylaxis reaction in rats \& } \\
\text { antagonism of the histamine action and } \\
\text { inhibition of allergic mediators (Park et } \\
\text { al., 2002). }\end{array}$ \\
\hline $\begin{array}{l}\text { Benincasa } \\
\text { hispida }\end{array}$ & Fruit Pulp & Metanolic Extract & $\begin{array}{l}\text { Histamine \& Ach Induced } \\
\text { Bronchospasm(Anilkumar D., } \\
\text { Ramu,2002) }\end{array}$ \\
\hline Boswellia serrata & Root & $\begin{array}{l}\text { Boswellin, boswellic } \\
\text { acids }\end{array}$ & $\begin{array}{l}\text { Inhibit LT biosynthesis and block } \\
\text { synthesis of 5-HETE \& LTB4 } \\
\text { (Gupta,1998) }\end{array}$ \\
\hline Curcuma longa & Rhizome & $\begin{array}{l}\text { Tumerones, } \\
\text { curcuminoids }\end{array}$ & $\begin{array}{l}\text { Inhibits histamine release from rat } \\
\text { peritoneal mast cells (Ammon \& } \\
\text { Wahl,1991) }\end{array}$ \\
\hline $\begin{array}{l}\text { Eugenia } \\
\text { caryophylis }\end{array}$ & $\begin{array}{l}\text { Flower } \\
\text { buds, } \\
\text { leaves }\end{array}$ & Eugenol & $\begin{array}{l}\text { Antianaphylaxis, inhibits C 48/80 } \\
\text { induced anaphylaxis(Sharadini,1985) }\end{array}$ \\
\hline Picrorhiza kurroa & Roots & Picrorrhizin & $\begin{array}{l}\text { Inhibits release of histamine and SRS-A } \\
\text { (Doshi \& Shetge, 1983) }\end{array}$ \\
\hline $\begin{array}{l}\text { Solanum } \\
\text { xanthocarpum }\end{array}$ & Herb & Salasodin & $\begin{array}{l}\text { Bronchodilator (Govindan \& } \\
\text { Viswanathan, 1999) }\end{array}$ \\
\hline $\begin{array}{l}\text { Tenospora. } \\
\text { cardoifofia }\end{array}$ & Stem & Aqueous extract & $\begin{array}{l}\text { Mast cell stabilizing activity } \\
\text { (Nayampalli \& Desai,1986) }\end{array}$ \\
\hline $\begin{array}{l}\text { Tamarandus } \\
\text { indica }\end{array}$ & $\begin{array}{l}\text { Whole } \\
\text { plant }\end{array}$ & $\begin{array}{l}\text { Indolizidine } \\
\text { alkaloid. }\end{array}$ & $\begin{array}{l}\text { Bronchodilatory, membrane stabilizing } \\
\text { (Sharadini,1985) }\end{array}$ \\
\hline Vitex. negundo & Leaves & Alcoholic extract & $\begin{array}{l}\text { Bronchodilatory, membrane stabilizing } \\
\text { (Saraf \& Nair,1995) }\end{array}$ \\
\hline $\begin{array}{l}\text { Calotropis } \\
\text { gigantea }\end{array}$ & Flower & $\begin{array}{l}\alpha \& \beta \text { calotropeol, } \beta- \\
\text { amyrin, ,giganteol }\end{array}$ & $\begin{array}{l}\text { Bronchodilator anti-inflammatory } \\
\text { (Sangraula and Kumar 1999) }\end{array}$ \\
\hline $\begin{array}{l}\text { Calotropis } \\
\text { procera }\end{array}$ & Flower & $\begin{array}{l}\alpha \& \beta \text { calotropeol, } \\
\beta \text {-amyrin, giganteol }\end{array}$ & $\begin{array}{l}\text { Bronchodilator anti-inflammatory } \\
\text { (Sangraula and Kumar 1999) }\end{array}$ \\
\hline
\end{tabular}




\begin{tabular}{|l|l|l|l|}
\hline Plant & Part used & $\begin{array}{l}\text { Extract/Active } \\
\text { principle }\end{array}$ & Probable action in asthma \\
\hline Cedrus deodara & Wood & Himacholol & $\begin{array}{l}\text { Mast cell stabilizing activity (Shinde } \text { et } \\
\text { al., 1999) }\end{array}$ \\
\hline $\begin{array}{l}\text { Centipeda } \\
\text { minima }\end{array}$ & $\begin{array}{l}\text { Whole } \\
\text { plant }\end{array}$ & $\begin{array}{l}\text { Pseudoguainolid,ses } \\
\text { quiterpen,lactones, } \\
\text { flavonoids }\end{array}$ & $\begin{array}{l}\text { Inhibits passive cutaneous anaphylaxis } \\
\text { in rats (Wu } \text { et al., 1985) }\end{array}$ \\
\hline $\begin{array}{l}\text { Clerodendrum } \\
\text { serratum }\end{array}$ & Leaves & Aqueous extract. & Bronchodilator (Gupta, S.S., 1994) \\
\hline Inula. racemosa & Roots & Aqueous, alcoholic & $\begin{array}{l}\text { Anti-histaminic, Anti-serotonergic } \\
\text { (Srivastava et al., 1999) }\end{array}$ \\
\hline $\begin{array}{l}\text { Sarcostemm } \\
\text { brevistigma }\end{array}$ & Twigs & Alkaloid fraction & $\begin{array}{l}\text { Inhibits passive cutaneous anaphylaxis } \\
\text { in rates (Saraf and Patwardhan,1998) }\end{array}$ \\
\hline $\begin{array}{l}\text { Tephrosia } \\
\text { purpurea }\end{array}$ & $\begin{array}{l}\text { Whole } \\
\text { plant }\end{array}$ & Ethanolic extract & $\begin{array}{l}\text { Bronchodilatory, antianaphylactic } \\
\text { (Gokhale and Saraf,2000) }\end{array}$ \\
\hline
\end{tabular}

Table 3.

\section{Bronchodilator activity of two combined component of alkaloidal fraction of Ailanthus excelsa Roxb}

Asthma is a chronic inflammatory disease that affects about 300 million people worldwide, a total that is expected to rise to about 400 million over the next 15-20 years (Kumar et al., 2010a) Ailanthus is a deciduous tree belonging to the family Simarubaceae, and widely distributed in Asia and North Australia. Commonly it is known as a Plant of Heaven. The bark of this plant is used as an anthelminthic, expectorant, antiasthmic, antispasmodic and antipyretic (Kumar et al., 2010b). Ailanthus excelsa is reported to be useful in a many ailments like asthma, allergy, bronchoconstriction etc. In the present study two combined Component of alkaloidal fraction of stem bark of Ailanthus excelsa Roxb.(AFAE) was for the first time evaluated for its bronchodilator activity.

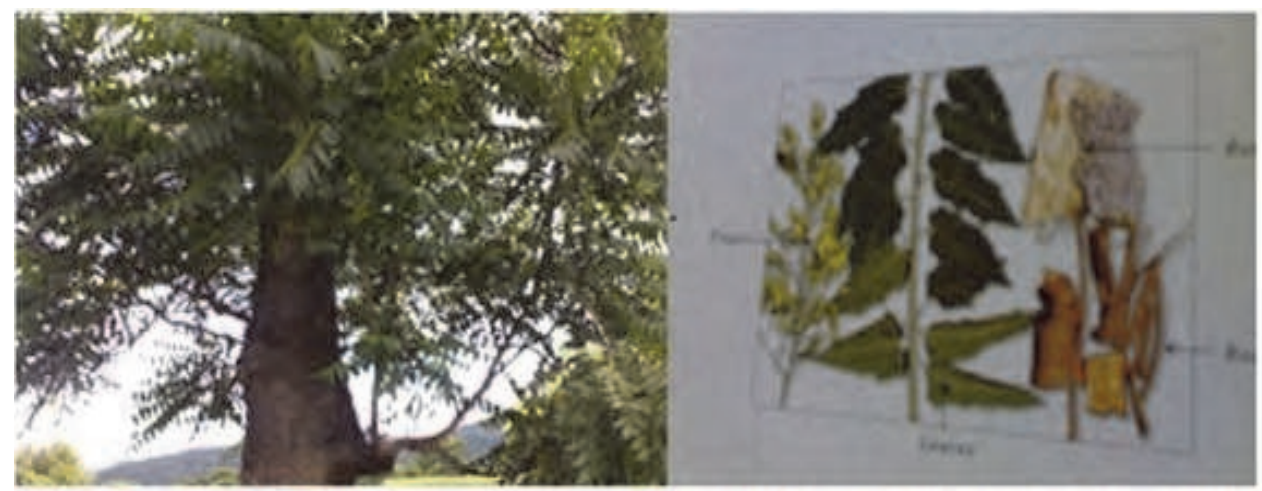

Plant A. excelsa Roxb.

Flowers, Leaves and Barks of A. excelsa Roxb.

Fig. 4 . 


\subsection{Materials and methods}

Plant material: Stem barks of Ailanthus excelsa Roxb were collected in Aug. 2008 from local area of Pimpri, pune-18 (INDIA) and identified by the RRI of Ayurveda Kothrude, Pune (INDIA). A voucher specimen - 899 was authenticated. Stem barks were dried, powdered, passed through 40 mesh sieve. The powdered material was extracted with methanol $(95 \%)$ using soxhlet apparatus (10\%). The brown extract (2gm) of stem bark of Ailanthus excelsa roxb. was used to prepare an alkaloidal rich fraction. The alkaloidal fraction was $500 \mathrm{mg}$ and this Alkaloidal fraction was subjected to column chromatography for isolation of pure constituents using different polarity solvent and silica (60-120) as adsorbent. The component was isolated in chloroform: methanol (4:1) proportion $(50 \mathrm{mg})$ and the same was checked for its purity by performing TLC in Beznene: methanol (4:1) solvent system. A single spot with Rf value of 0.56 was recorded. The isolated sample was then subjected to GC-MS which however showed the same to be a mixure of two components having close resemblance to each other and the fragmentation pattern was almost same and the retention time gap was very small. The molecular weights were 413 and 429 . Alkaoidal tests were positive for the constituents.

Animal: Albino rats (Wistar strain) and mice (musmusculus strain) of either sex weighing $150-200 \mathrm{gm}$ rats and $20-25 \mathrm{gm}$ mice respectively were used. They were housed in microlon boxes with standard laboratory diet and water ad libitum. The study was conducted after obtaining Institutional Animal Ethical Committee clearance (198/99/CPCSEA).

Acute toxicity studies: AFAE was safe upto $1000 \mathrm{mg} / \mathrm{kg}$ and based on the results of preliminary toxicity testing the doses of 10,20 and $40 \mathrm{mg} / \mathrm{kg}$ p.o were chosen for further experiments.

\subsection{Bronchodilator activity}

Effect of test drug on isolated goat trachea chain preparation: Isolated adult Goat tracheal tissue was obtained immediately after slaughter of the animals. Trachea was cut into individual rings and tied together in series to form a chain. Trachea was suspended in bath of Kreb's solution which was continuously aerated and maintained at $37 \pm 0.5^{\circ} \mathrm{C}$. Tissue was allowed to equilibrate for $45 \mathrm{~min}$. under a load of $400 \mathrm{mg}$. A dose response curve for histamine was taken in variant molar concentrations, by maintaining 15 min time cycle. After obtaining a dose response curve of histamine on trachea, the AFAE was added to the respective reservoir and same doses of histamine were repeated. Graph of percentage of maximum contractile response on ordinate and negative logarithm of molar concentration of histamine on abscissa were plotted to record dose response curve of histamine, in absence and in presence AFAE (Bhujbal et al., 2009).

Milk induced leukocytosis and eosinophilia: Mice were divided into five groups, six animals in each group. Animals belonging to group-I received distilled water (DW) 10 $\mathrm{ml} / \mathrm{kg}$, (p.o.). Animals belonging to group II, III, IV, V received boiled and cooled milk injection in dose of $4 \mathrm{ml} / \mathrm{kg}$, (s.c.). Animals belonging to groups III, IV and V received AFAE in dose 10, 20 and $400 \mathrm{mg} / \mathrm{kg}$, p. o. respectively, $1 \mathrm{hr}$ before milk injection. Blood samples were collected from each mouse from the retro orbital plexus, under light ether anaesthesia. Total leukocyte count and total eosinophilia count was done in each group before drug administration and $24 \mathrm{hr}$ after milk injection. Difference in Total leukocyte count and total eosinophilia count before and $24 \mathrm{hr}$ after drug administration was calculated. 
Clonidine-induced Mast Cell Degranulation: Rats were divided into five groups, six animals in each group. Animals belonging to group-I received vehicles $5 \mathrm{ml} / \mathrm{kg}$, (p.o.) Animals belonging to group-II received Sodium cromoglycate $50 \mathrm{mg} / \mathrm{kg}$, (i.p.). Animals belonging to group-III, IV and V received AFAE in dose $(10,20$ and $40 \mathrm{mg} / \mathrm{kg}$, p.o.) respectively. The treatment was continued for 7 days. On day 7 th, 2 hour after the assigned treatment mast cells were collected from the peritoneal cavity. $10 \mathrm{ml}$ of normal saline solution was injected into peritoneal cavity and abdomen was gently massaged for 90 second. The peritoneal cavity was carefully opened and the fluid containing mast cells was aspirated and collected in siliconised test tube containing 7 to $10 \mathrm{ml}$ of RPMI-1640 Medium ( $\mathrm{pH} 7.2-7.4)$. The mast cells were then washed thrice by centrifugation at low speed (400-500 rpm) and the pallet of mast cells were taken in the medium. The mast cells suspension approximately $\left(1 \times 10^{6}\right.$ cells $\left./ \mathrm{ml}\right)$ was challenged with $0.5 \mu \mathrm{g} / \mathrm{ml}$ of clonidine solution and stained with $1 \%$ toluidine blue and observed under high power microscope field $(400 \mathrm{X})$. Total 100 cells were counted from different visual areas and the number of intact and degranulated cells was counted. The percent protection was calculated (Kumar et al., 2009).

Bronchoalveolar lavage and lung histology in rats: Animals were divided into five groups each group containing six animals. All the animals were sensitized by an intraperitoneal injection of $1 \mathrm{ml}$ alum precipitate antigen containing $20 \mu \mathrm{g}$ of ovaalbumin and $8 \mathrm{mg}$ of alum suspended in $0.9 \%$ sodium chloride solution. A booster injection of this alum-ovalbumin mixture was given 7 days later. Non sensitized animals were injected with alum only. Seven days after (15th day) second injection animals were exposed to aerosolized ovaalbumin(1\%) for $30 \mathrm{~min}$. Standard \& test group was received Dexamethasone $(1 \mathrm{mg} / \mathrm{kg}$, i.p.) as standard and AFAE 10, 20, $40 \mathrm{mg} / \mathrm{kg}$ as test drug, $5 \mathrm{hr}$ before antigen challenge. The rats were sacrificed at the end of study ( $24 \mathrm{hr}$ after sensitization) and tracheal catheter was inserted in trachea. Bronchoalveolar lavage fluid was collected by lavaging the lung with 2 aquilots of $5 \mathrm{ml}$ of $0.9 \%$ sodium chloride solution total recovery volume per rat was approximately $8 \mathrm{ml}$. Total leukocytes and eosinophiles, neutrophiles were counted under microscope and Histopathological evaluation of lung tissue was carried out (Kumar et al, 2010c).

\subsection{Statistical analysis}

All values were expressed as mean \pm S.E.M. and data were analysed by ANOVAs followed by dennest.

\section{Results}

\begin{tabular}{|c|c|c|c|c|c|}
\hline $\begin{array}{c}\text { Fraction } \\
\text { quantity }\end{array}$ & $\begin{array}{c}\text { Solvent } \\
\text { proportion }\end{array}$ & $\begin{array}{c}\text { Yield } \\
(\mathrm{mg})\end{array}$ & colour & Identification test & $\begin{array}{c}\text { TLC benzene: } \\
\text { methanol (4:1) }\end{array}$ \\
\hline $500 \mathrm{mg}$ & $\begin{array}{c}\text { Chloroform: } \\
\text { methanol (80:20) }\end{array}$ & $50 \mathrm{mg}$ & brown & $\begin{array}{c}\text { UV- 365 flurosent, } \\
\text { positive for } \\
\text { alkaloids }\end{array}$ & $\begin{array}{c}\text { Single spot with Rf } \\
\text { value - 0.56. }\end{array}$ \\
\hline
\end{tabular}

Table 4. Isolation and Characterization of AFAE

a. Alkaloidal fraction: U.V spectroscopy: UV $\lambda$ max. -282, 242, 220, IR range: 


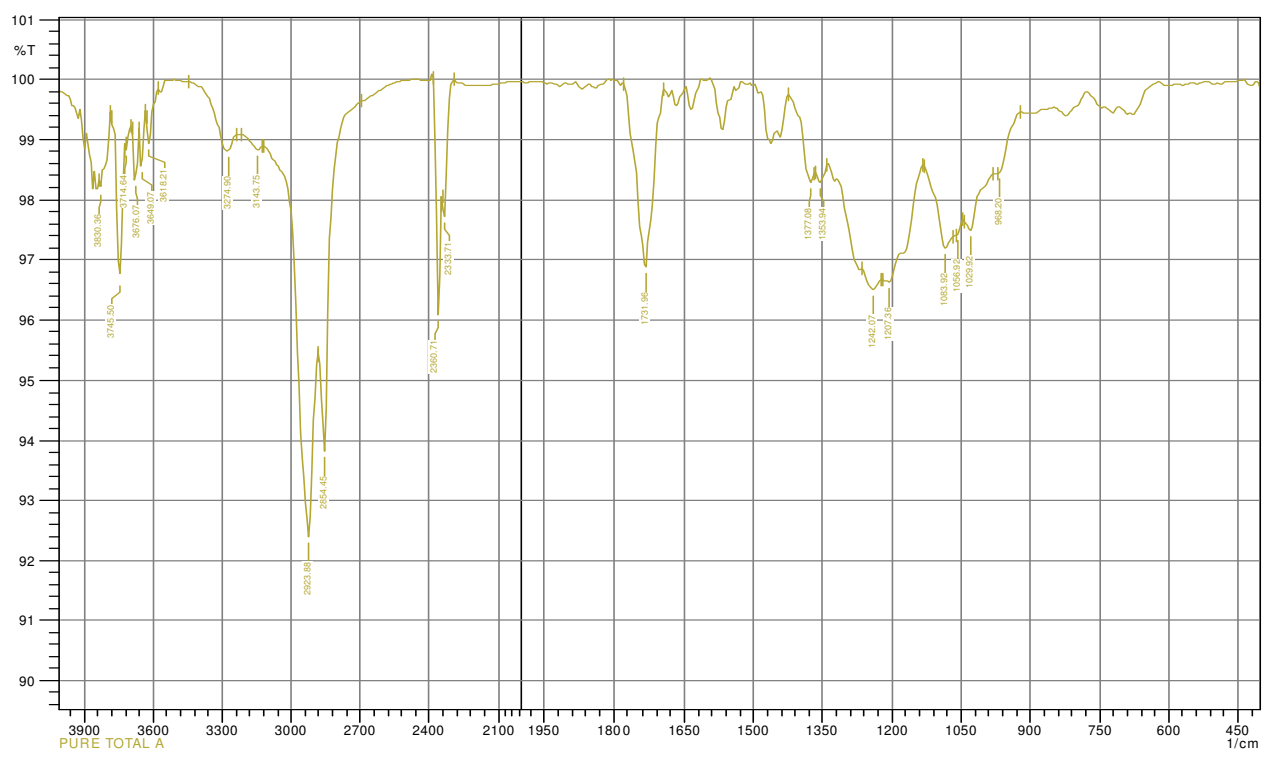

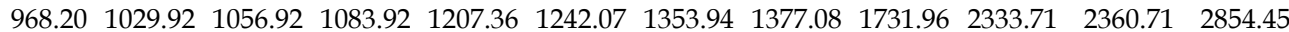
$2923.88 \quad 3143.753274 .90 \quad 3618.213649 .073676 .07 \quad 3714.64 \quad 3745.50 \quad 3830.36$.

Fig. 5.

b. AFAE: U.V spectroscopy: UV $\lambda$ max. - 209, 220, IR range:

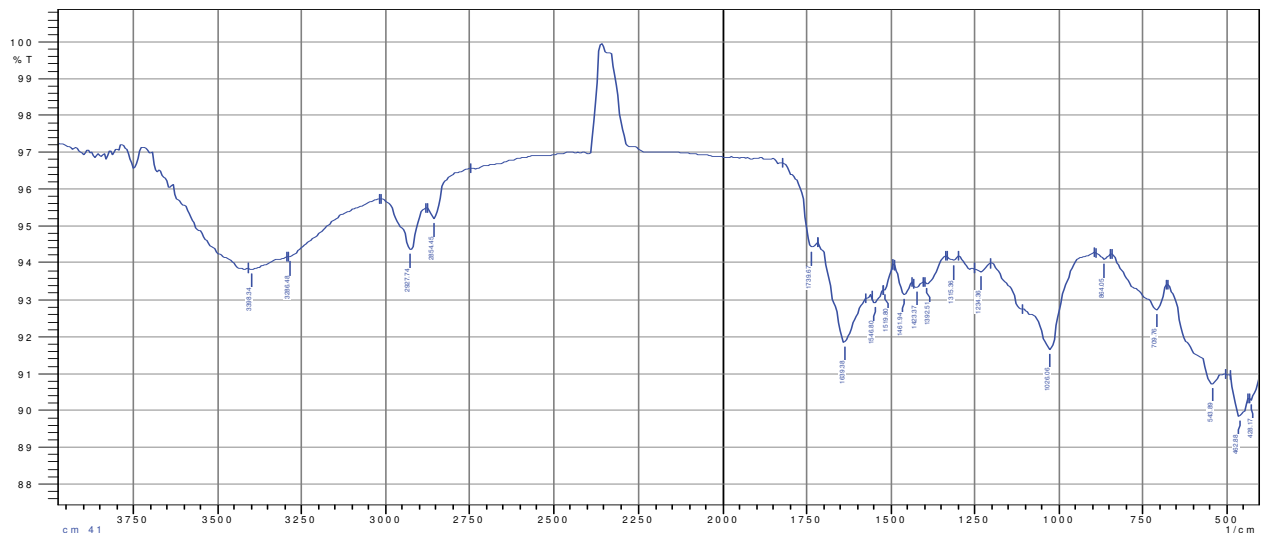

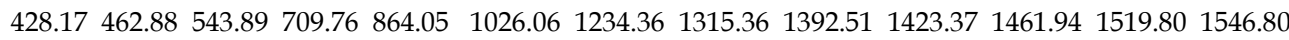
1639.381739 .672854 .452927 .743286 .483398 .34$.

Fig. 6. 


\section{SATC \\ Department of Chemistry \\ University of Pune \\ Pune 411007}

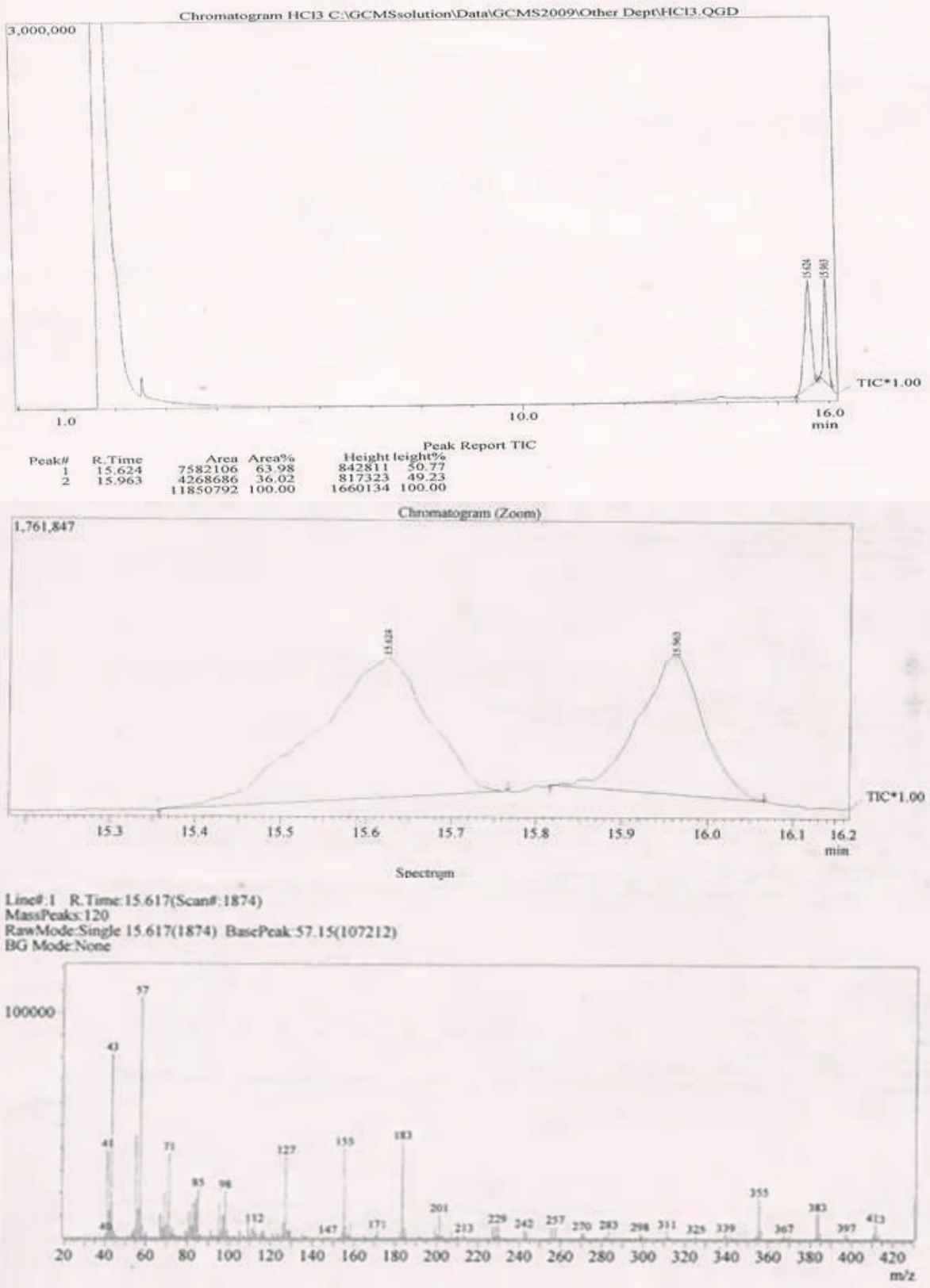




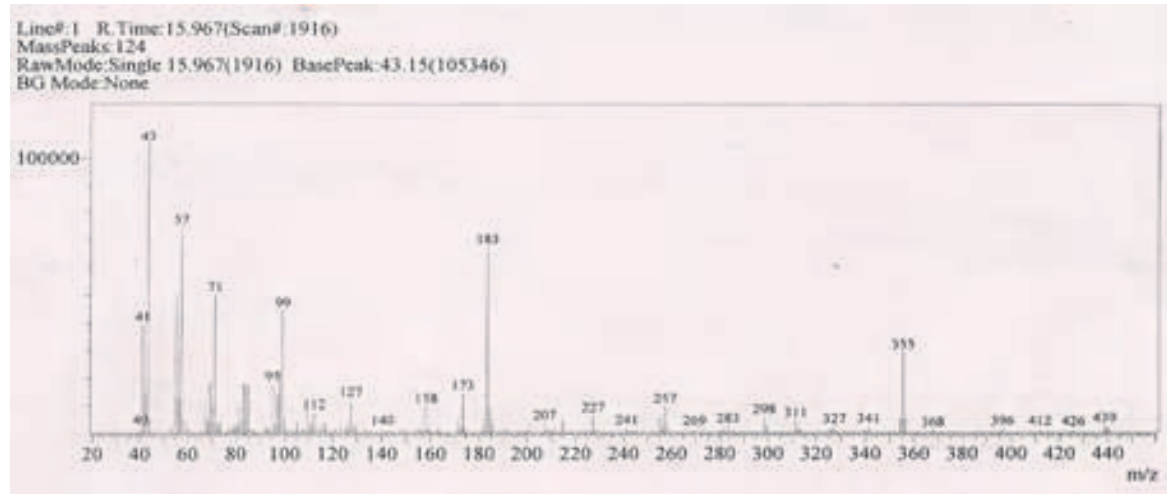

GC-MS

Fig. 7. The above compounds having very less retention time and they have similar ion peaks so in their structure there may be the possibilities of similarity.

\subsection{Bronchodilator activity: In vitro}

Effect of AFEA $(30 \mu \mathrm{g} / \mathrm{ml})$ on Histamine induced contraction of isolated goat tracheal chain preparation: In the present study, it was observed that AFAE inhibits the contraction produced by histamine in these tissue preparations. Histamine $(10 \mu \mathrm{g} / \mathrm{ml})$ was taken in different dose level and DRC was plotted in absence and in presence of Ailanthus excelsa extract. Study showed that AFAE inhibits significantly $\left({ }^{*} p<0.05,{ }^{* *} p<0.01,{ }^{* * *} p<0.001\right)$ percentage contraction at concentration $30 \mu \mathrm{g} / \mathrm{ml}$ in goat tracheal chain preparation. Dose dependent response relationship was seen (Figure 8).

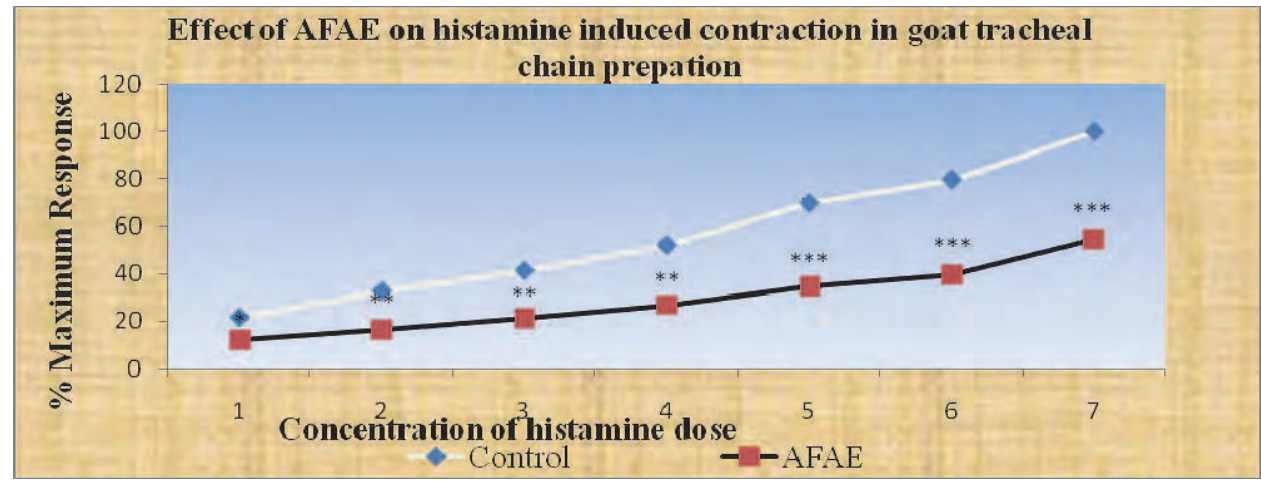

$\mathrm{n}=6$, Values are in Mean \pm SEM. Control $=$ D.R.C. of Histamine in absence of AFAE. AFAE $=$ D.R.C. of Histamine in presence of AFAE $(30 \mu \mathrm{g} / \mathrm{ml})$. Statistical analysis done by using Student's $\mathrm{s}^{\prime} \mathrm{t}^{\prime}$-test. $\left({ }^{*} \mathrm{p}<0.05\right.$, $\left.{ }^{* *} \mathrm{p}<0.01,{ }^{* * *} \mathrm{p}<0.001\right)$, significantly different from control.

Fig. 8 .

\subsection{In - vivo}

Milk induced leukocytosis and eosinophilia: Subcutaneous injection of milk at dose of 4 $\mathrm{ml} / \mathrm{kg}$ produced a significant $\left({ }^{* * *} \mathrm{p}<0.001\right)$ increase in the leucocytes and eosinophiles count 
after $24 \mathrm{hr}$ of its administration. In the groups of mice pretreated with AFAE at dose (10 $\mathrm{mg} / \mathrm{kg}, 20 \mathrm{mg} / \mathrm{kg}$ and $40 \mathrm{mg} / \mathrm{kg}$, p.o.), there was significant $\left({ }^{*} \mathrm{p}<0.05,{ }^{* *} \mathrm{p}<0.01\right)$ inhibition of milk-induced Leucocytosis and eosinophilia (Figure $9 \& 10$ ).

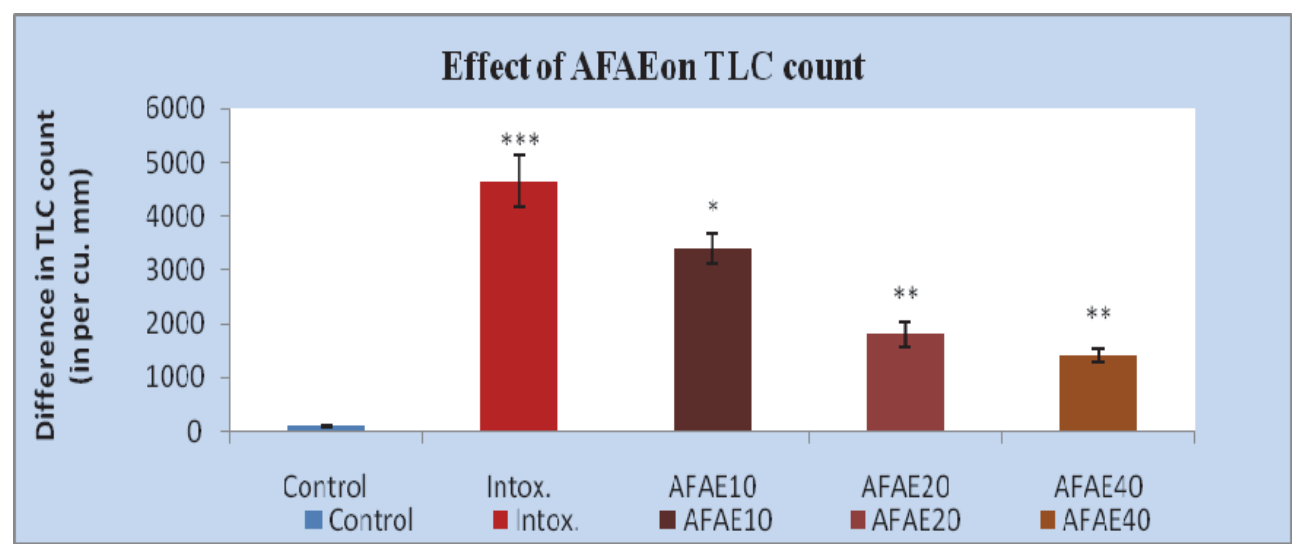

$\mathrm{n}=6$, values are expressed in mean \pm SEM. Control $=$ Vehicle $(10 \mathrm{ml} / \mathrm{kg}$, p.o.). Intox. $=$ milk $4 \mathrm{ml} / \mathrm{kg}$, ${ }^{* * *} \mathrm{p}<0.001$, Intox. group compared with control group using student't, test and ${ }^{*} \mathrm{p}<0.05,{ }^{* *} \mathrm{p}<0.01$, AFAE compared to intox. Group using Statistical analysis done by ANOVA followed by Dunnet's test.

Fig. 9. Effect of AFAE on TLC count

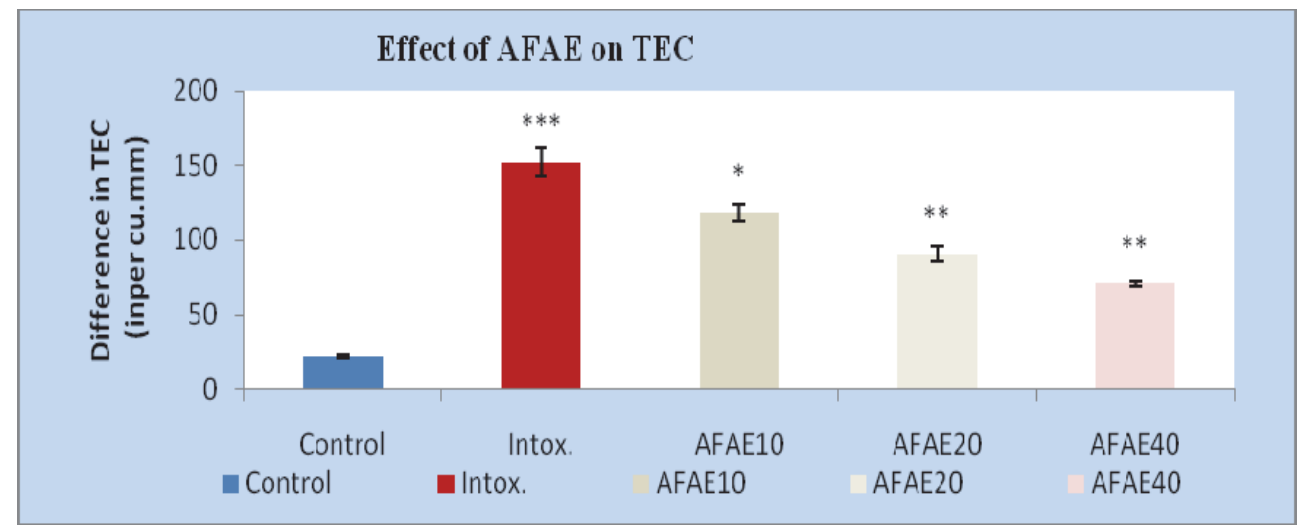

$\mathrm{n}=6$, values are expressed in mean \pm SEM. Control $=$ Vehicle $(10 \mathrm{ml} / \mathrm{kg}$, p.o. $)$. Intox. $=$ milk $4 \mathrm{ml} / \mathrm{kg}$, ${ }^{* * *} p<0.001$, Intox. group compared with control group using student't, test and ${ }^{*} p<0.05,{ }^{* *} p<0.01$, AFAE compared to intox. Group using Statistical analysis done by ANOVA followed by Dunnet's test.

Fig. 10. Effect of AFAE on TEC

Effect of AFAE on clonidine-induced mast cell degranulation in rats: Clonidine induced mast cell degranulation was significantly $\left({ }^{* *} \mathrm{p}<0.01\right)$ inhibited by sodium cromoglycate $(50$ $\mathrm{mg} / \mathrm{kg}$, i.p.) and percent protection was found to be $68.42 \%$. In the groups pre-treated AFAE $(10,20,40 \mathrm{mg} / \mathrm{kg}, \mathrm{p} . \mathrm{o})$ there was significant protection $\left({ }^{* *} \mathrm{p}<0.01\right)$ of mast cells and the percent protection was 37.89, 54.21, and $61.42 \%$ respectively (Figure 11). 


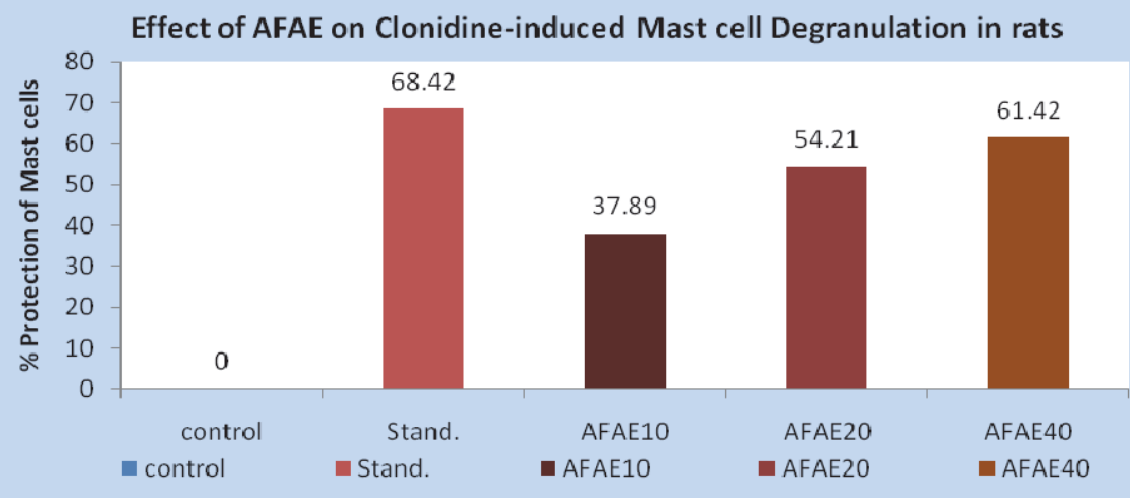

$\mathrm{n}=6$, values are expressed in mean \pm SEM. Control $=$ Distilled water $(5 \mathrm{ml} / \mathrm{kg}$, p.o. $)$. Std. $=$ Sodium cromoglycate $(50 \mathrm{mg} / \mathrm{kg}$, i.p.), Std., AFAE10, AFAE20, AFAE40 compared with Control (ANOVA followed by Dunnett's test), ${ }^{* *} \mathrm{p}<0.01$.

Fig. 11. Effect of AFAE on Clonidine-induced Mast cell Degranulation in rats

Effect of AFAE on Bronchoalveolar lavage in rats: Persistent mucosal airway inflammation, associated with an increase in T helper type 2 (Th2) cytokine levels, eosinophil infiltration into the airways, and mucus and immunoglobulin ( $\mathrm{IgE}$ ) production, are the main features of allergic asthma. The infiltration of cells like eosinophils, neutrophils, monocytes, macrophages, lymphocytes, etc., increases the allergic asthmatic effect. Injection of ovalbumin $20 \mu \mathrm{g}+8 \mathrm{mg}$ alum in $1 \mathrm{ml}$ (i.p.) on days 1 and 7 and 1\% OVA aerosol on 15th day produced a significant $\left({ }^{* *} P<0.001\right)$ increase in the TLC. In the groups pretreated with standard drug dexamethasone $\left(1 \mathrm{mg} / \mathrm{kg}\right.$ i.p.), there was a significant $\left({ }^{* *} P<0.01\right)$ inhibition of ovalbumin-induced TLC and differential leukocyte count. The AFAE at doses of 10, 20, and $40 \mathrm{mg} / \mathrm{kg}$ showed significant decrease in TLC and neutrophils, lymphocytes and monocytes, macrophages and eosinophils $\left({ }^{*} P<0.05,{ }^{* *} P<0.01\right.$ [Table 5]. AFAE40

\begin{tabular}{|c|c|c|c|c|c|c|c|}
\hline \multirow{2}{*}{$\begin{array}{c}\text { Sr. } \\
\text { No. }\end{array}$} & \multirow{2}{*}{ Groups } & \multicolumn{6}{|c|}{ Recoverable BAL Cells $\left(\times 1 \mathbf{3}^{3} / \mathbf{l}\right)($ Mean \pm SEM) } \\
\cline { 3 - 8 } & & Total Cells & Neutrophile & Eosinophils & Lymphoctes & Monocytes & $\begin{array}{c}\text { Alveolar } \\
\text { Macrophages }\end{array}$ \\
\hline 1. & NS & $186 \pm 8.12$ & $19.6 \pm 3.69$ & $13 \pm 1.55$ & $6 \pm 1.34$ & $4 \pm 0.71$ & $4.8 \pm 0.58$ \\
\hline 2. & S & $820 \pm 57.09^{* * *}$ & $122 \pm 10.08^{* * *}$ & $79.8 \pm 4.13^{* * *}$ & $39.2 \pm 3.8^{* * *}$ & $19.8 \pm .74^{* * *}$ & $16.6 \pm 1.08^{* * *}$ \\
\hline 3. & Std & $218 \pm 7.84^{* *}$ & $52.6 \pm 1.17^{* *}$ & $32.4 \pm 3.98^{* *}$ & $10.6 \pm 0.66^{* *}$ & $6.8 \pm 0.66^{* *}$ & $6.2 \pm 1.36^{* *}$ \\
\hline 4. & AFAE10 & $384 \pm 24.97^{* *}$ & $98.4 \pm 7.17^{*}$ & $66 \pm 4.44$ & $18.4 \pm 2.06^{* *}$ & $13 \pm 1.05^{* *}$ & $12 \pm 0.71$ \\
\hline 5. & AFAE20 & $322 \pm 26.91^{* *}$ & $76.8 \pm 3.61^{* *}$ & $56.2 \pm 2.71^{* *}$ & $18.6 \pm 1.03^{* *}$ & $12 \pm 0.95^{* *}$ & $13.2 \pm 0.97^{* *}$ \\
\hline 6. & AFAE40 & $246 \pm 12.39^{* *}$ & $66.2 \pm 3.64^{* *}$ & $45.2 \pm 4.83^{* *}$ & $13.3 \pm 1.50^{* *}$ & $9.4 \pm 0.86^{* *}$ & $9.6 \pm 0.81^{* *}$ \\
\hline
\end{tabular}

$\mathrm{n}=6$, values are expressed in mean \pm SEM. NS $=$ Non Sensitized group, Distilled water $+8 \mathrm{mg}$ alum in 1 $\mathrm{ml}$ (i.p.). $\mathrm{S}=$ Sensitized group, Ovaalbumin $20 \mu \mathrm{g}+8 \mathrm{mg}$ alum in $1 \mathrm{ml}$ (i.p.) 1,7 day and $1 \%$ OVA aerosol on 15 day. Std. $=$ Dexamethasone $\left(1 \mathrm{mg} / \mathrm{kg}\right.$, i.p.). NS compared with $S$ by using student't, test ${ }^{* * *} \mathrm{p}<0.001$ and Std., AFAE10, AFAE20, AFAE40 compared with S (ANOVA followed by Dunnett's test), ${ }^{*} \mathrm{p}<0.05$, ${ }^{* *} \mathrm{p}<0.01$.

Table 5. Effect of AFAE on Bronchoalveolar lavage in rats 
Effect of AFAE on Histopathological evaluation of Lung Tissue: The histopathological evaluation of lung tissue showed the reduction of inflateration and mediators of brnchoconstruction. The AFAE showed significant bronchodilator activity. Light micrograph of rat lungs collected from different treatment groups and the lungs were fixed in formalin and embedded in paraffin wax. Section of lung tissue were cut at $5 \mu \mathrm{m}$ thickness, mounted on glass slides, stained with hematoxylin and eosin $(\mathrm{H} \times \mathrm{E})$ and cells were identified as either eosinophils, neutrophils or mononuclear cells by standard morphology and 200 cells counted under 400X magnification (Figure 12).

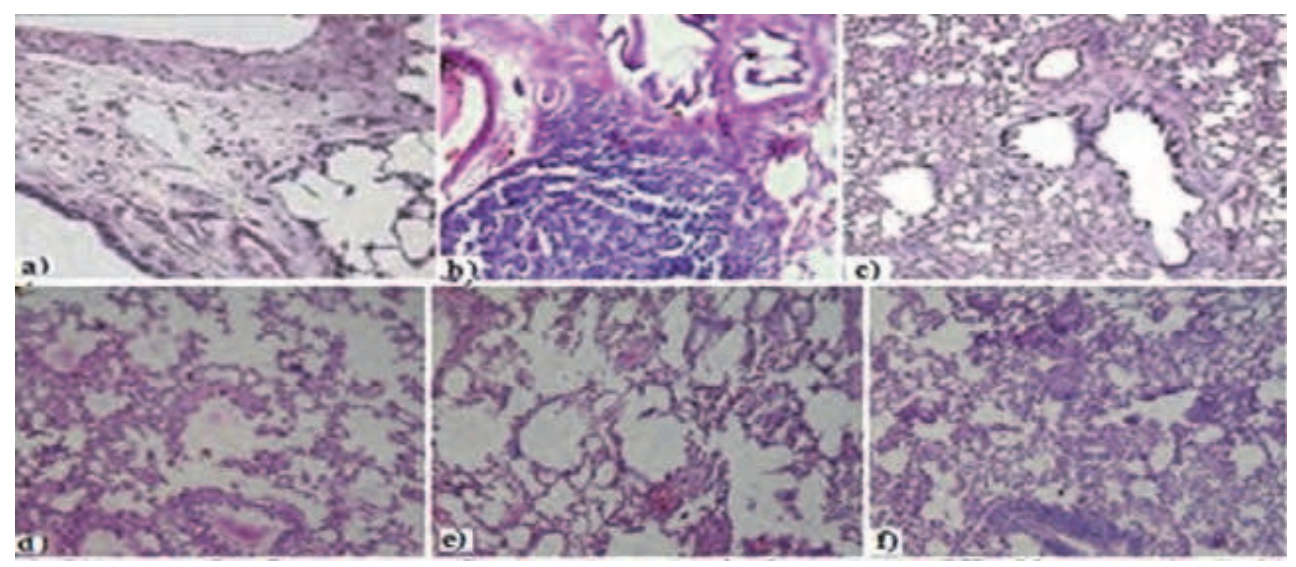

Fig. 12. Effect of AFAE on histopathological evaluation of lung tissue.

Where $a)=$ Abscence of imfalmmatory cells, no edema in the lung tissue (NS- Non sensitized). $b$ ) = Abscess formation, fluid accumulation along with inflammatory cells, blood cells, edema (S- Sensitized). c) = a low magnification lung section from an antigenchallenged animals received (standard) dexamethasone (1mg/ kg i.p.) showing abscence of fluid accumulaton around the blood vessel. $d$ ) = AFAE10 showing haemorrhages, emphysema, MNC and edema. e) = AFAE20 showing emphysema, MNC and haemorrhages. $\mathrm{f}$ ) = AFAE40 showing emphysema.

\section{Discussion}

The role of plants serving as purifiers of air has been known to us, since times immemorial. To cope with the gradually increasing levels of toxic pollutants, tree plantation programs have been undertaken in different countries of the world to help in environmental cleanup. Ailanthus excelsa Roxb. (Simaroubaceae) is one such exotic avenue tree, the plantation of which has been encouraged under social forestry programs for large-scale tree plantation in different densely populated cities and towns of India [Mondal et al., 2007]. Histamine contracts the tracheobronchial muscle of guinea pig, goat, horse, dog and man. Goat tracheal chain is easier to handle and to prepare; it is also much more sensitive than guinea pig tracheal chain. Therefore, the dose relative contractile responses of different agonists like ACh, histamine, 5hydroxytryptamine and bradykinin can be observed in isolated goat trachea. In the present study the isolated goat tracheal chain preparation; there is right side shift of Dose Response Curve (DRC) of histamine in the presence of AFAE indicating Bronchodilation [Bhujbal et al., 2009]. In the rat mast cell granules, the histamine 
concentration has been calculated to be around 0.3 M. Both clonidine and compound 48/80 act through the dynamic expulsion of granules without causing any damage to the cell wall. Clonidine releases histamine from mast cells in a similar manner to a selective liberator like compound 48/80 [Lakdawala et al., 1980]. It is known that sodium cromoglycate; a standard mast cell stabilizer prevents degranulation of mast cells by raising the cyclic adenosine monophosphate. It has been known that all pharmacological agents that increase intracellular levels of cAMP relax airway smooth muscle and inhibit the release of autocoids from the tissue and basophils. The groups of animals pre-treated with AFAE resulted in a significant reduction in degranulation of mast cells and offered significant protection when challenged with clonidine indicating mast cell stabilizing activity which ultimately produces bronchodilation. The inflammatory response is characterized by an increase in the numbers of eosinophils and mast cells, mucus hypersecretion, and activation of $\mathrm{T}$ cells. Several studies have shown that T-helper type (Th2) cells play a major role in the initiation and maintenance of allergic airway inflammation and asthma through their increased production of Th2-type cytokines (IL-4, IL-5, and IL- 13). These inflammatory cytokines also produced in the bronchial tissue by mast cells, alveolar macrophages, and epithelial cells, play a significant role in the pathogenesis of airway inflammation. The inflammatory mediators produce bronchoconstriction and the PAE helps to reduce the mediator which leads to bronchodilation. Ovalbumin increases the neutrophils, eosinophils, macrophages, monocytes, leukocytes, lymphocytes, epithelial cells, mucus etc., in BALF and AFAE helps to reduce all the allergic factors [Kumar ett al., 2010c].

Thus, it can be concluded from the results obtained in the present investigation that AFAE possesses significant bronchodilating activity. Hence, further detailed study needs to be conducted to separate the constituents and individually evaluate these phytoconstituent responsible to produce the above result and their clinical efficacy in the treatment of asthmatic patients.

\section{Acknowledgement}

I would like to thank Dr. R. K. Nanda, Santosh S. Bhujbal and other staff members of Dr. D. Y. Patil IPSR Pune for guiding me to conduct this valuable work.

I would like to thank NCL- Pune scientists and library staff members for their sport and help for literature review.

I would like to thank NTC- Pune for providing animals and Dr. Surayawanshi for provinding histopathological evaluation (Omega labs. Pvt. Ltd.).

I would like to thank Dr. Rajesh Dabur for authentication of Plant in RRI-Pune, India. would like to attribute special thank to Late Popinder singh, Department of Pharmaceutical Sciences University of Kashmir-190006 for his content support and enouragement.

\section{References}

Ammon HP, Wahl MA. (1991). Pharmacology of Curcuma longa. Planta Medica, 57, pp. 11-7.

Anilkumar D, Ramu P. (2002). Effect of Methanolic extract of Benincasa hispida against histamine \& acetycholine induced bronchoplasm in Guinea pigs. Indian J. Pharmacology, 34, pp. 365-366.

Bhujbal SS, Kumar D, Deoda RS, Deore TK, Patil MJ. (2009). Antiasthmatic activity of roots of Hemidesmus indicus R. Br. Pharmacologyonline, 1, pp. 209-216. 
Calixto JB. (2000). Efficacy, safety, quality control, marketing and regulatory guidelines for herbal medicines (phytotherapeutic agents). Brazilian Journal of Medical and Biological Research, 33, 179-190.

Cragg GM, Newman DJ. (2005). International collaboration in drug discovery and development from natural sources. Pure Appl. Chem., 77, pp. 1923-1942.

Gokhale AB, Saraf MN. (2000). Studies on antiallergic activity of ethanolic extract of Tephrosia purpurea Linn. Indian Drugs, 37, 5, pp. 228-32.

Govindan SS, Viswanathan S. (1999). A Pilot Study on Clinical Efficacy of Solanum xanthocarpum and Solanum trilobatum in Bronchial Asthma. Journal of Ethnopharmacology, 66, pp. 205-210.

Gupta I, Gupta V, Parihar A. (1998). Effects of Boswellia serrata gum resin in patients with bronchial asthma: results of a double-blind, placebo-controlled, 6-week clinical study. Eur J Med Res, 3, 511-514.

Gupta SS. (1994). Prospects and perspectives of natural plants products in medicine. Indian Journal of Pharmacology, 26, 1 -12.

Handa SS. (2007). "Quality Control, Scientific Validation and Business Prospects of Medicinal and Aromatic Plants", Port of Spain, Trinidad \& Tobago, Medicinal and aromatic plants global industry overview, pp. 1-21.

Kumar D, Bhat ZA, Singh P, Shah MY, Bhujbal SS. (2010b). Ailanthus excelsa Roxb. is Really a Plant of Heaven. International Journal of Pharmacology, 6, 5, pp. 535-550.

Kumar D, Bhujbal SS, Deoda RS, Mudgade SC. Bronchodilator activity of aqueous extract of stem bark of Ailanthus excelsa Roxb. Phcog Res., 2, 102-106.

Kumar D, Bhujbal SS, Patil PS, Buge PV. In-vitro and in-vivo activities of stem bark of methanolic extract of Ailanthus excelsa Roxb. in the management of asthma. International Journal of Pharmacology 6, 3, 284-289.

Kumar D, Prasad DN, Parkash J, Bhatnagar SP, Kumar D. (2009). Antiasthmatic activity of ethanolic extract of Aerva lanata linn. Pharmacologyonline 2: 1075-1081.

Lakdawala A. D., Dadkar N. K., Dohadwalla A. N. Action of clonidine on the mast cells of rats. J Pharm Pharmacol., 32, 790-91.

Madhu V, Chinnaiah B, Swamy TN. (2010). Traditional herbal remedies to cure asthma in Adilabad district, Andhra Pradesh, India. IJPLS, 1,4, 217-221.

Mondal S (Parui), Mondal A, Mandal S. (2007). Evaluation of electroelution and immunodiffusion as methods for purification and identification of the allergenic proteins of Ailanthus excelsa Roxb. pollen. Grana, 46: 91-97.

Nayampalli SR, Desai NK. (1986). Antiallergic Activity of Tinospora cordifolia in Animal Models. Ind. J. Pharmacol., 18, pp. 250-252.

Park KH, Park J, Koh D, Lim Y. (2002). Effect of Saikosaponin-A, a triterpenoid glycosided isolated from Bupleurum falcatum on experimental allergic asthma, Phytother. Res., 16, pp. 359-363.

Sangraula H, Kumar VL. (1999). Anti-inflammatory studies on latex of Calotropics procera. Indian Journal of Pharmacology. 31, pp. 1-78.

Saraf MN, Patwardhan BK. (1988). Pharmacological studies on Sarcostemma brevistigma Whight part II. Bronchodilator activity. Indian Drugs, 26, pp. 54-57.

Sharadini A. (1985). Ayurveda revisited; Popular Prakasam Publication; Bombay, pp. 1-2.

Singh S. Agrawal S. (1990). Bronchorelaxant activity of Belamcanda chinensis (Adans).; Ind. J. Pharmacol., 22, pp. 107-109. 
Srivastava S, Gupta PP, Prasad R, Dixit KS, Palit G. (1999). Evaluation of antiallergic activity (type I hypersensitivity) of Inula racemosa in rats. Indian J. Pharmacol., 43, 2, pp. 235-241.

Tripathi RM, Das PK. (1977). Studies on antiasthmatic and antianaphylactic activity of Albizzia lebbeck, Ind. J. Pharmacol., 9, pp. 189-194.

Wu JB, Chun YT, Ebizuka Y, Sankawa V. (1985). Biologically active constituents of Centipeda minima: isolation of a new phenolin ester and the antiallergic activity of sesquiterpene lactones. Chem. Pharm. Bull., 33, pp. 4091-4094.

Zuckerman GB. (1986). Leonard Bielory., (2002). Complementary and Alternative Medicine Herbal Therapies for Atopic Disorders. 


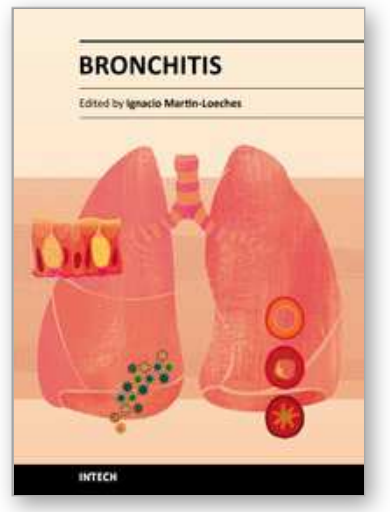

\author{
Bronchitis \\ Edited by Dr. Ignacio MartÃn-Loeches
}

ISBN 978-953-307-889-2

Hard cover, 190 pages

Publisher InTech

Published online 23, August, 2011

Published in print edition August, 2011

Lung parenchyma has been extensively investigated. Nevertheless, the study of bronchial small airways is much less common. In addition, bronchitis represents, in some occasions, an intermediate process that easily explains the damage in the lung parenchyma. The main target of this book is to provide a bronchial small airways original research from different experts in the field.

\title{
How to reference
}

In order to correctly reference this scholarly work, feel free to copy and paste the following:

Dinesh Kumar, Zulfiqar Ali Bhat, Ishtiaq Ahmad Chashoo, Ramesh S. Deoda, Satish C. Mudgade and Vijender Kumar (2011). Bronchodilator Activity in Traditional Medicines: Gift of God Kingdom, Bronchitis, Dr. Ignacio MartÃn-Loeches (Ed.), ISBN: 978-953-307-889-2, InTech, Available from:

http://www.intechopen.com/books/bronchitis/bronchodilator-activity-in-traditional-medicines-gift-of-godkingdom

\section{INTECH}

open science | open minds

\section{InTech Europe}

University Campus STeP Ri

Slavka Krautzeka 83/A

51000 Rijeka, Croatia

Phone: +385 (51) 770447

Fax: +385 (51) 686166

www.intechopen.com

\section{InTech China}

Unit 405, Office Block, Hotel Equatorial Shanghai

No.65, Yan An Road (West), Shanghai, 200040, China

中国上海市延安西路65号上海国际贵都大饭店办公楼 405 单元

Phone: +86-21-62489820

Fax: $+86-21-62489821$ 
(C) 2011 The Author(s). Licensee IntechOpen. This chapter is distributed under the terms of the Creative Commons Attribution-NonCommercialShareAlike-3.0 License, which permits use, distribution and reproduction for non-commercial purposes, provided the original is properly cited and derivative works building on this content are distributed under the same license. 